\title{
Related factor in lamentation risk of low back pain on inpatient nurse
}

\author{
Andi Achmad Awaludin ${ }^{1)}$; Lukmanulhakim ${ }^{2 *}$ \\ 1 RSUD dr. Dradjat Prawiranegara Serang \\ ${ }^{2 *)}$ Sekolah Tinggi Ilmu Kesehatan Faletehan Serang Banten
}

\section{ARTICLE INFO}

\section{Article history:}

Received May 10, 2019

Revised May 21, 2019

Accepted May 22, 2019

\section{Keyword:}

Low Back Pain

Symptoms of LBP

Work Period

Work Posture

\section{*) corresponding author}

STIKes Faletehan Serang. Jl Raya Cilegon KM.06 Desa Pelamunan Kramatwatu Serang Banten 42161

Email:

lukmanulhakimshodrudin@yahoo.com

DOI:https://doi.org/10.30604/jika.v4i2.196

\begin{abstract}
A B S T R A C T
Low back pain (LBP) is one of the musculoskeletal disorders caused by poor body activity. This study aims to determine the factors associated with the risk of LBP complaints of nurse in the ward at the Banten Provincial Hospital. The research method used was analytic observational through cross sectional approach. The research respondents were 34 nurses who were selected by using probability sampling with cluster sampling type. The measurement of age, work period, and BMI used respondent characteristics form, work posture measurement used RULA, and the measurement of LBP complaints used the LBP symptom questionnaire. The statistical test used the chi square test with a significant level $(\alpha \leq 0.05)$. The test results of the relationship between individual characteristics and the risk of LBP complaints obtained age $(p=0.677)$, work period $(p=0.811), B M I(p=0.350)$, and the relationship between work posture and the risk of LBP complaints $(p=0.000)$. Based on the results of research statistics, it was found that there was no significant relationship between age, work period, and BMI with the risk of LBP complaints and there was a relationship between work posture and the risk of LBP complaints. The researcher suggested that the nurse should pay attention to their work posture when conducting a nursing intervention.
\end{abstract}

This is an open access article under the CC-BY-SA license.

\section{INTRODUCTION}

Low Back Pain is a musculoskeletal disorder that is often felt in the lower back region and it is caused by various bodily diseases and activities that are not good (Sumangando, Rottie, \& Lolong, 2017). Health and safety executive data in 2016, in the United Kingdom of Great Britain, the number of workers suffering from occupational diseases was 1.3 million, in 2013/2014 of the country, there were 310 cases of workers experiencing 
LBP, and an estimated 150 new cases (Health and safety executive, 2014).

Nelson., \& Baptiste (2006), revealed that LBP high-risk workers are workers who work with awkward postures, manual handling with higher frequency and duration, including health workers in hospitals, especially in nurses in work areas that have a lot of lifting. The number of back pain sufferers toward nurses in the Netherlands and Cape Town is $36 \%$ to $63 \%$. Whereas for the Asian continent, such as in Korea there were $72 \%$, Thailand $61.5 \%$ and China $56 \%$ (Naude, 2009). In this case, it is reinforced by what was written in the Kepmenkes (2010), that hospital workers have a higher risk compared to other industrial workers in the case of occupational diseases, so it is necessary to set standards of protection for workers in hospitals.

Work activities in hospitals have the potential for occupational diseases. As the Frontline in providing health services, the nursing profession is the highest risk of experiencing medical professional LBP (Wong., Teo., \& Kyaw, 2010). This is evidenced by what has been identified by Kurniawidjaja., Purnomo., Maretti., \& Pujiriani, (2014) in his research that as many as $65 \%$ of nurses in the Intensive Care Unit of Jakarta Fatmawati Hospital were diagnosed with LBP, and medical record data at the Prikasih Hospital in the period of January-December 2010 showed that nurses affected by LBP were 59 people $(34.7 \%)$.

Several other studies also revealed the same thing as what had been done by nudity, Utami, \& Utami (2015), at Awal Bros Hospital in Pekanbaru identified 39 nurses (19.5\%) from a total of 200 nurses suffering from LBP. The same thing has been identified at the dr. Dradjat Prawiranegara Serang Banten Hospital from the number of respondents 37 nurses, obtained results of $45.9 \%$ have a low risk, $35.1 \%$ in the medium category (Lukmanulhakim \& Solihin, 2017).
Duthey (2013), identified that LBP can occur to everyone, both gender, age, race, educational status and profession, one of which is the nursing profession. Nurses have a very important role and function in providing health services, such as what has been stated by Rezaee., \& Ghasemi (2014), that the provision of health services by nurses to patients under management, is required to provide great time and energy in meeting every need the patient's basis thus resulting in an increased risk of LBP complaints.

Nurses in the inpatient room can be said to be at high risk of experiencing LBP complaints, several risk factors that have been identified by previous researchers Fathoni., Handoyono. \& Swasti (2012), that the risk factors for LBP complaints include age, body mass index, obesity, pregnancy and psychological factors. Someone who is elderly will experience LBP due to decreased bodily functions, especially bones, so they are no longer elastic like when they were young.

Other risk factors for LBP complaints are found in Sakinah (2012), which explains that the length of service of a nurse is closely related to physical abilities, the longer the nurse works the physical abilities decrease, so that fatigue can occur due to muscle contractions and abdominal support, this is indirectly indicated as a risk of LBP complaints. Furthermore, although the effect is relatively small, body mass index is one of the factors causing the risk of LBP complaints, nurses who have excess body weight are at greater risk of low back pain, because the burden on the joints of weight gain increases, so as to allow the occurrence of low back pain. Tarwaka, \& Sudiajeng (2004), explained that a person who has excess weight will increase the risk of LBP complaints, because it can affect other body parts such as the back and legs to support the weight. Weight gain can increase the burden on the backbone.

Nurses in their work use a lot of movements such as bending, turning the body, lifting 
heavy objects and lifting patients is the biggest risk factor for LBP. That work is often done, including lifting or transferring patients who are done repeatedly with poor ergonomic actions ultimately results in LBP (Karahan., Kav., Abbasoglu., \& Dogan, 2009).

The preliminary survey results of researchers through a brief interview conducted in several nurses inpatients in Banten Provincial Hospital found a complaint in the form of low back pain in the lumbar region when taking action, but will disappear after a break, generally the activities that nurses do during work are putting up an IV, lifting and move the patient, change the dressing and push the patient. Based on the characteristics of nurses in the Banten General Hospital, the majority are aged 20-35 years, with a period of work > 5 years and weight with the category of overweight. Looking for the above description, the purpose of this research is to analyze the factors associated with the risk of complaints of Low Back Pain (LBP) in Inpatient Installation Nurses of Banten Province Hospital.

\section{METHOD}

This type of research is an observational analysis through cross sectional approach, which aims to look for factors related to the risk of LBP complaints in nurses in patient installations. This research was conducted at the Banten Provincial Hospital on January 14-24 2019. The population in this research was all nurses who worked in the Banten Province Hospital inpatient installation, amounting to 101 people. The type of sample used in this research is probability sampling with cluster sampling method (Sugiyono, 2008). Where the sampling technique chose several areas in the inpatient room taken from 3 rooms with a sample of 34 people.

Data collection tools used in this research were LBP Complaints Risk questionnaire which was adopted from The Pain and Distress Scale (Zung, 1983) which was then developed by Primala (2012). And the RULA worksheet instrument for measuring the Rapid Upper Limb Assessment work posture was developed by McAtamney, \& Corlett (1993), as well as a Geniometer measurement tool to determine the degree of body and camera posture.

The data collection process is carried out first by coordinating with the relevant room, and then the researcher begins by observing by photographing risky work postures when the respondent carries out his daily activities. Researchers made an informed consent to respondents and distributed other questionnaire sheets to respondents. After all observations and instruments have been filled, then the photos / camera results from various angles obtained will be analyzed by measuring the angle of the nurse's body by using a Geniometer gauge and giving a score on the RULA worksheet.

The collected data is then performed a statistical test to find out the correlation between the two variables using the ChiSquare Test with $\alpha 0.05$ significance.

\section{RESULTS AND DISCUSSION}

\section{Table 1.}

Frequency Distribution of Respondent

Characteristics based on Age, Years of Service, BMI

\begin{tabular}{lcc}
\hline $\begin{array}{c}\text { Respondent } \\
\text { Characteristics }\end{array}$ & Frequency & $\%$ \\
\hline Age & 1 & $2.9 \%$ \\
< 25 year & 23 & $67.6 \%$ \\
25-35 year & 10 & $29.4 \%$ \\
$\quad>$ 35 year & & \\
\hline Years of Service & 5 & $14.7 \%$ \\
$\quad$ < 5 year & 22 & $64.7 \%$ \\
5-10 year & 7 & $20.6 \%$ \\
> 10 year & & \\
BMI & 0 & 0 \\
BB Underweight & 6 & $17.6 \%$ \\
Normal & 28 & $82.4 \%$ \\
BB Overweight & &
\end{tabular}

The univariate analysis in this research was used to provide an overview of the characteristics of respondents based on their age, years of service and BMI of nurses. 
Nurse's working posture and LBP Nurse complaints in Banten hospital inpatient installation

Based on Table 1. The results show that from 34 respondents aged $<25$ years as many as 1 person $(2.9 \%)$, age $25-35$ years 23 people $(67.6 \%)$ and age > 35 years 10 people (29.7\%). The working period of respondents $<5$ years as many as 5 people $(14.7 \%)$, years of service in 5-10 years 22 people $(64.7 \%)$ and the tenure of $>10$ years 7 people (20.6\%). Respondents with normal weight were 6 people $(17.6 \%)$, with overweight $\mathrm{BB}$ (more) 28 people $(82.4 \%)$.

Table 2.

Frequency Distribution of Inpatient nurses' Working Postures

\begin{tabular}{lcc}
\hline Working Postures & Frequency & $\%$ \\
\hline Ignored & 3 & $8.8 \%$ \\
Low & 22 & $64.7 \%$ \\
Moderate & 7 & $20.6 \%$ \\
High & 2 & $5.9 \%$ \\
\hline
\end{tabular}

Table 2. show that from 34 respondents found respondents with a risk of being ignored by 3 people $(8.8 \%)$, low risk by 22 people $(64.7 \%)$, moderate risk by 7 people $(20.6 \%)$ and risk high as much as 2 people $(5.9 \%)$.

Table 3.

Frequency Distribution of LBP Complaints by Nurses of Inpatient Nurses'

\begin{tabular}{lcc}
\hline \multicolumn{1}{c}{ Risk of LBP } & Frequency & \% \\
\hline Normal & 19 & 55.9 \\
Mild & 8 & 23.5 \\
Moderate & 5 & 14.7 \\
High & 2 & 5.9 \\
\hline
\end{tabular}

Based on table 3. The results show that from 34 respondents found 19 people $(55.9 \%)$ did not complain about LBP (normal), 8 people $(23.5 \%)$ mild risk, 5 people $(14.7 \%)$ moderate risk, 2 people (5.9\%) high risk.

The univariate analysis in this research was used to provide an analysis of the relationship between age, years of service, BMI, nurses' work posture with the risk of LBP complaints by nurses in the inpatient installation of the Banten Public Hospital.

Table 4.

The Correlation between Age, Years of Service, BMI and Work Posture with LBP Complaints Risk.

\begin{tabular}{|c|c|c|c|c|c|c|}
\hline \multirow[b]{2}{*}{ Variable } & \multicolumn{4}{|c|}{ LBP Complaints Risk } & \multirow[b]{2}{*}{ Total } & \multirow[b]{2}{*}{ p value } \\
\hline & $\begin{array}{c}\text { Normal } \\
\text { n }(\%) \\
\end{array}$ & $\begin{array}{c}\text { Mild } \\
\text { n }(\%) \\
\end{array}$ & $\begin{array}{c}\text { Moderate } \\
\text { n }(\%) \\
\end{array}$ & $\begin{array}{l}\text { High } \\
\text { n (\%) }\end{array}$ & & \\
\hline \multicolumn{7}{|l|}{ Age } \\
\hline$<25$ year & $1(2,9 \%)$ & $0(0,0 \%)$ & $0(0,0 \%)$ & $0(0,0 \%)$ & 1 & \multirow{3}{*}{0,677} \\
\hline 25-35 year & $14(41,1 \%)$ & $6(17,6 \%)$ & $2(5,8 \%)$ & $1(2,9 \%)$ & 23 & \\
\hline$>35$ year & $4(11,7 \%)$ & $2(5,8 \%)$ & $3(8,8 \%)$ & $2(5,8 \%)$ & 10 & \\
\hline \multicolumn{7}{|l|}{ Years of Service } \\
\hline$<5$ year & $3(8,8 \%)$ & $2(5,8 \%)$ & $0(0,0 \%)$ & $0(0,0 \%)$ & 5 & \multirow{3}{*}{0,811} \\
\hline 5-10 year & $12(35,2 \%)$ & $5(14,7 \%)$ & $4(11,7 \%)$ & $1(2,9 \%)$ & 22 & \\
\hline$>10$ year & $4(11,7 \%)$ & $1(2,9 \%)$ & $1(2,9 \%)$ & $1(2,9 \%)$ & 7 & \\
\hline \multicolumn{7}{|l|}{ BMI } \\
\hline BB Underweight & $0(0,0 \%)$ & $0(0,0 \%)$ & $0(0,0 \%)$ & $0(0,0 \%)$ & 0 & \multirow{3}{*}{0,350} \\
\hline Normal & $2(5,8 \%)$ & $3(8,8 \%)$ & $1(2,9 \%)$ & $0(0,0 \%)$ & 6 & \\
\hline BB Overweight & $17(50 \%)$ & $5(14,7 \%)$ & $4(11,7 \%)$ & $2(5,8 \%)$ & 28 & \\
\hline \multicolumn{7}{|l|}{ Working Postures } \\
\hline Ignored & $2(5,8 \%)$ & $0(0,0 \%)$ & $1(2,9 \%)$ & $0(0,0 \%)$ & 3 & \multirow{4}{*}{0,000} \\
\hline Low & $15(44,1 \%)$ & $5(14,7 \%)$ & $2(5,8 \%)$ & $0(0,0 \%)$ & 22 & \\
\hline Moderate & $2(5,8 \%)$ & $3(8,8 \%)$ & $2(5,8 \%)$ & $0(0,0 \%)$ & 7 & \\
\hline High & $0(0,0 \%)$ & $0(0,0 \%)$ & $0(0,0 \%)$ & $2(5,8 \%)$ & 2 & \\
\hline
\end{tabular}


Based on table 4. The results of statistical analysis between age and LBP Complaints obtained p-value (0.677), so it was concluded there was no relationship between age and LBP complaint risk. The highest number of respondents at the age of 25-35 years with no complaints of LBP (Normal) was 14 people $(41.1 \%)$.

The results of this research are in line with what has been found by Maizura (2015), there is no significant relationship between age and LBP complaints. However, in another study conducted by Defriyan (2011), obtained different results and stated that there was a significant relationship between age and risk of LBP complaints with p-value (0.045). The discrepancy in this case is due to differences in categorizing the age of respondents who categorize the age to be $\geq$ 35 years and $<35$ years also the differences in the distribution of samples in the research.

Asghar (2012), stated that LBP complaints generally occur between the ages of 25 to 64 years. The peak LBP prevalence is between the ages of 35 to 55 years. The difference between the results of the research and the theory is that most nurses in inpatients are aged 25-35 years, in this case the majority of nurses have enough experience, both in work experience and experience to minimize stresses on the body due to work, and make a way of life healthy by exercising regularly to increase stamina.

Furthermore, table 4, also shows the results of statistical analysis between tenure and LBP complaints obtained $p$-value (0.811), so it can be concluded that there is no significant relationship between years of service and LBP complaint risk. Most of the respondent's years of service is 5-10 years, namely as many as 22 people, and almost half of respondents with the above working period do not experience LBP complaints (Normal) of $35.2 \%$, with mild LBP complaints by $14.7 \%$ and moderate complaints by $11.7 \%$.
The results of this research were not in line with what Lukmanulhakim, \& Solihin (2017) found, which identified that there was a significant relationship between tenure with LBP complaints, and Pratiwi., Setyaningsih., Kurniawan., \& Martini. (2012), which states that someone who has worked $>5$ years of work is more at risk of developing back pain compared to those who work $\leq 5$ years.

Work period is the period of time or the length of time a worker is at a workplace. During the activity, a nurse such as lifting, changing, dressing, infusion which is done with a high work period and is carried out continuously in a position that is not static can result in excessive muscle stretching so that narrowing occurs in the permanent intervertebral discs which results in spinal degeneration and then raises LBP.

Suma'mur (2009), explains that the longer a person works, the more he is exposed to the dangers posed by the work environment. Discrepancies in the results of this research are assumed to be differences in the characteristics of the sample used, in which the research sample is emergency nurses who have high work volumes and work performed is required to be fast and precise because of limited time. While nurses in patient installation in performing nursing actions such as infusion and dressing dressing are not done at any time and continuously in one shift so that inpatients have more rest time.

The results of statistical analysis between the Body Mass Index and LBP complaints obtained p-value (0.350), and concluded that there was no significant relationship between body mass index (BMI) and the risk of LBP complaints. The results of this study identified half of the respondents $(50.0 \%)$ were overweight (overweight BB), as many as 17 people $(50.0 \%)$ did not experience LBP complaints, while $14.7 \%$ with mild complaints, $11.7 \%$ with moderate complaints and $5.8 \%$ with LBP complaints of severe categories. 
The same thing is obtained from the results of this study that there is no conformity with what has been found by Setyaningrum (2014), who has previously identified that there is a significant relationship between Body Mass Index (BMI) and the risk of complaints of low back pain.

Some experts claim that a fat body size has twice the risk compared to a thin body size. Umami., Hartanti., \& Sujoso, (2014), suggested that someone who had an abnormal BMI had a risk of experiencing complaints in the lower back region twice as high as respondents with a normal BMI.

Other statistical analysis results that measure the work posture with LBP complaints obtained p-value $(0,000)$, which can be assumed that there is a significant relationship between work posture and the risk of LBP complaints. This study identified almost half of the respondents who had low ergonomic work postures with LBP complaints by 15 people $(44.1 \%)$, while non ergonomic work potions had high categories with LBP complaints risk by $5.8 \%$. The results of this study are in line with what had been previously discovered by Lukmanulhakim., \& Solihin (2017); Meizura (2015), who identified that there is a significant relationship between work shorter and the risk of LBP complaints.

Risk of LBP complaints is closely related to work postures that are not ergonomic when doing activities Bending is a nurse's work position that is impossible to avoid, especially when providing services to patients who are lying in bed, bending is a position to bend the backbone towards the frontal which would certainly burden intervertebral discs, and also increases the contraction of the ligaments and muscles supporting the spine. This is in line with what was stated by Hinmikaiye, \& Bamishaiye (2012), that rapid movements are accompanied by poor posture, especially when nurses perform under time pressure such as in the emergency room.
The bending posture is a very risky posture, because when flexion occurs muscle tension (strain) especially in the interspinosus and supraspinosus ligaments, followed by intrascapular ligament and ligamentum flavum. In addition, the compressive load on the disc during flexion makes the disc potentially able to tear the annulus fibrosis, consequently the nucleus pulposus is able to escape through this tear. This is reinforced by what has been said by Naude (2009), that the position taken such as bending for a long period or the same posture can be a risk factor for LBP. Karahan., Kav., Abbasoglu., \& Dogan (2009), also revealed the same thing that the work that was often done, including lifting or moving patients who were done repeatedly with poor ergonomic actions eventually resulted in LBP.

In detail in this research, the measurement of the respondent's work posture when conducting activities were observed and measured using RULA with the results of the majority of respondents at risk in the neck area with a slope of $30^{\circ}$ and body / torso $55^{\circ}$. This is similar to what has been done by Nico. , Haslegrave., \& Chaffin, (2005) with the results of the calculation of the slope angle of the neck area of $30^{\circ}$ and the body part of the $60^{\circ}$.

The results of various studies and theories corroborate the results of observations using RULA where RULA scores with moderate or high risk categories are obtained from nurses' observations when replacing the dressing with a bending posture with a tilt angle of $55^{\circ}$. These activities are routine activities every day, if carried out continuously with work postures that are not ergonomic can affect posture, causing LBP complaints.

\section{CONCLUSIONS AND SUGGESTIONS}

Nurses' work postures that are not carried out ergonomically while doing their daily activities can result in and risk experiencing LBP complaints. Jobs such as lifting and moving patients who are done repeatedly, 
bending for a long time can be a risk factor for complaints of Low Back Pain. The results of this study prove and inform nurses, nurses who work in an inpatient installation are needed to pay attention to work postures ergonomically, and some aspects that must be considered by nurses include administrative control and control techniques that are adjustable both by nurses and management managers Hospital.

\section{REFERENCE}

Asghar, N. A. (2012). Low Back Pain. Edited by Ali Asghar Norasteh. ISBN 13: 9789535105992. Croatia: Intech. Retrieved from : https://www.intechopen.com/books/lo w-back-pain

Defriyan. (2011). Faktor-faktor yang berhubungan dengan keluhan nyeri punggung bawah pada proses penyulaman kain tapis di sanggar family art Bandar Lampung Tahun 2011. (Skripsi), UIN Press. Jakarta. Retrieved from

http://repository.uinjkt.ac.id/dspace/bit stream/123456789/26310/1/DEFRIYA N-FKIK.pdf

Duthey, B. (2013). Background paper 6.24 low back pain. Priority medicines for Europe and the world. Global Burden of Disease (2010),(March), 1-29. Retrieved from : Retrieved from : http://apps.who.int/medicinedocs/en/m /abstract/Js20271en/

Fathoni, H., Handoyono., \& Swasti K.G. (2012). Hubungan sikap danposisi kerja dengan low back pain pada perawat RSUD Purbalingga. Jurnal Keperawatan Soedirman, 7(2), 86-92. Retrieved from http://www.jks.fikes.unsoed.ac.id/inde X.php/jks/article/view/360

Health and Safety Executive. (2014). HSE annual statistics report for great britain.
Practically the results of this study can be recommended as a medium of information for nurses to maintain ergonomic posture when performing nursing actions. Hospital management is responsible for occupational safety and health, is obliged to carry out management as a form of protection of workers' rights in accordance with laws and regulations. Control techniques by using a bed and gurney transportation and adjustable bench instead of a static model.

Diakses pada [04/12/2019] Retrieved from

http://www.hse.gov.uk/statistics/

Hinmikaiye, C. D., \& Bamishaiye, E. I. (2012). The incidence of low back pain among theatre nurses: a case study of University of Ilorin and Obafemi Awolowo University Teaching Hospital. International Journal of Nursing Science, 2(3), 23-28. Retrieved from

http://article.sapub.org/10.5923.j.nursi ng.20120203.02.html

Karahan, A., Kav, S., Abbasoglu, A., \& Dogan, N. (2009). Low back pain: prevalence and associated risk factors among hospital staff. Journal of advanced nursing, 65(3), 516-524. Retrieved from https://www.ncbi.nlm.nih.gov/pubmed/ 19222649

Kepmenkes RI. (2010). Standar kesehatan dan keselamatan kerja di RS. Jakarta: Direktorat Bina Kesehatan Kerja Kemenetrian Kesehatan RI. Retrieved from

https://galihendradita.files.wordpress.c om/2015/03/kmk-no-1087-2010-ttgstandar-k3rs.pdf

Kurniawidjaja, L. M., Purnomo, E., Maretti, N., \& Pujiriani, I. (2014). Pengendalian Risiko Ergonomi Kasus Low Back Pain pada Perawat di 
Rumah Sakit. Majalah Kedokteran Bandung, 46(4), 225-233. Retrieved from

http://journal.fk.unpad.ac.id/index.php/ mkb/article/view/342

Lukmanulhakim, E., \& Solihin, R. (2017). The Relationship beetween work posture and risk for low back pain complaint of emergency department nurses in dr. Drajat Prawiranegara General Hospital Serang Banten. Jurnal ilmu Keperawatan, 5(2), 161171.

doi:

http://dx.doi.org/10.21776/ub.jik.2017. $\underline{005.02 .6}$

Maizura, F. (2015). Faktor-faktor yang berhubungan dengan keluhan nyeri punggung bawah (NPB) pada pekerja di PT Bakrie Metal Industries tahun 2015. (Skripsi), UIN Press, Jakarta. Retrieved from

http://repository.uinjkt.ac.id/dspace/ha ndle/123456789/29632

McAtamney, L., \& Corlett, E. N. (1993). RULA: a survey method for the investigation of work-related upper limb disorders. Applied ergonomics, 24(2), 91-99. doi: https://doi.org/10.1016/00036870(93)90080-S

Naude, B. (2009). Factors associated with low back pain in hospital employees (Doctoral dissertation Faculty of Health Sciences) University of the Witwatersrand, Johannesburg. Retrieved form

https://www.researchgate.net/publicati on/265309574_Factors_Associated_wi th_Low_Back_Pain_in_Hospital_Empl oyees

Nelson, A., \& Baptiste, A. S. (2006). Evidence-based practices for safe patient handling and movement. Orthopedic nursing, 25(6), 366-79. Retrieved from https://www.ncbi.nlm.nih.gov/pubmed/ 17130758
Nico Dr, D. J., Haslegrave Dr, C. M., \& Chaffin Dr, D. B. (2005). Working postures and movements: tools for evaluation and engineering. Taylor \& Francis, Inc. Retrieved from : https://trove.nla.gov.au/work/1140675 $\underline{3}$

Nurdiati, W., Utami,G.T. \& Utami, S. (2015). Pengaruh latihan Peregangan Terhadap penurunan Intensitas Nyeri pada Perawat yang menderita Low Back Pain (LBP). Jurnal Online Mahasiswa (JOM), 2(1), 600-605. Retrieved from https://jom.unri.ac.id/index.php/JOMP SIK/article/view/8340

Pratiwi H, M., Setyaningsih, Y., Kurniawan, B., \& Martini, M. (2012). Beberapa Faktor Yang Berpengaruh Terhadap Keluhan Nyeri Punggung Bawah Pada Penjual Jamu Gendong. Jurnal Promosi Kesehatan Indonesia, 4(1), 61-67. Retrieved from https://ejournal.undip.ac.id/index.php/j pki/article/view/2429

Primala, A. (2012). Hubungan Aktivitas Kerja Manual Handling Dan Keluhan Nyeri Punggung Bawah (Low Back Pain) Pada Tenaga Kerja Produksi Sheet Metaldi Bagian Workshop I Garuda Maintenance Facility Aero Asia. (Skripsi), Universitas Esa Unggul, Jakarta. Retrieved from : https://digilib.esaunggul.ac.id/hubunga n-aktivitas-kerja-manual-handling-dankeluhan-nyeri-punggung-bawah-lowback-painpada-tenaga-kerja-produksisheet-metal-di-bagian-workshop-i-ptgaruda-maintenance-facility-aero-asia569.html

Rezaee, M., \& Ghasemi, M. (2014). Prevalence of low back pain among nurses: predisposing factors and role of work place violence. Trauma monthly, 19(4). 9-14. Retrieved from https://www.ncbi.nlm.nih.gov/pmc/arti cles/PMC4310160/ 
Sakinah, R. D., \& Naiem, F. (2012). Faktor yang Berhubungan dengan Keluhan Nyeri Punggung Bawah pada Pekerja Batu Bata di Kelurahan Lawawoi Kabupaten Sidrap. Repository Universitas Hasanuddin. Makassar: FKM UNHAS. Retrieved from : http://repository.unhas.ac.id/handle/12 3456789/6701

Setyaningrum, M. S. (2014). Hubungan Indeks Massa Tubuh Dengan Angka Kejadian Low Back Pain Di RSUD Dr. Moewardi Surakarta (Doctoral dissertation, Universitas Muhammadiyah Surakarta). Retrieved form : http://eprints.ums.ac.id/28360/

Sugiyono. (2008). Metode penelitian pendidikan, pendekatan kuantitatif, kualitatif dan $R \& D$. Bandung : Alfabeta. Retrieved from : https://scholar.google.co.id/scholar?clu $\underline{\text { ster }=10328650190657588078}$

Suma'mur. (2009). Hygiene perusahaan dan kesehatan kerja (Hiperkes). Jakarta: Sagung Seto. Retrieved from : https://scholar.google.co.id/scholar?clu $\underline{\text { ster }=5210908381918037831}$

Sumangando, M., Rottie, J. \& Lolong J. (2017). Hubungan beban kerja dengan kejadian Nyeri pinggang bawah (LBP) pada perawat pelaksana Di RS TK III R.W Mongisidi Manado. Ejournal Keperawatan,. 5(1), 1-9. Retrieved from

https://ejournal.unsrat.ac.id/index.php/j kp/article/view/14717/14285

Tarwaka, S. H., \& Sudiajeng, L. (2004). Ergonomi untuk keselamatan, kesehatan kerja dan produktivitas. UNIBA : Surakarta. Retrieved from : https://scholar.google.co.id/scholar?clu ster $=12307517266450775885$

Umami, A. R., Hartanti, R. I., \& Sujoso, A. D. P. (2014). Hubungan antara Karakteristik Responden dan Sikap Kerja Duduk dengan Keluhan Nyeri
Punggung Bawah (Low Back Pain) Pada Pekerja Batik Tulis (The Relationship Among Respondent Characteristic and Awkward Posture with Low Back Pain in Batik Workers). Pustaka Kesehatan, 2(1), 72-78. Retrieved from : https://jurnal.unej.ac.id/index.php/JPK/ article/view/599

Wong, Ts., Teo, N., \& Kyaw. (2010). Prevalence and risk factors assosiated with low back pain among health care providers in district hospital. Malaysian Ortopedic Journal, 4(2), 23-28. Retrieved from : https://www.morthoj.org/2010v4n2/Lo w_Back_Pain.pdf

Zung, W.W.K (1983). A self-rating pain and distress scale. Psychosomatics, 24(10), 887-890, 892-894. doi: https://doi.org/10.1016/S00333182(83)73140-3 
J urnal Aisyah: J urnal Ilmu Kesehatan, 4(2), December 2019, - 100 Andi Achmad Awaludin; Lukmanulhakim 